(From the Laboratory of the Waterworks, Rotlerdam).

\title{
AN IMPROVEMENT IN THE BACTO-TRYPTONE, SODIUM FORMATE MEDIUM FOR THE DETECTION OF B. COLI
}

\author{
by
}

\section{T. FOLPMERS}

(Received December 20, 1943).

An improvement of the bacto-tryptone, sodium formate medium ${ }^{1}$ ), which has now been put on trial for nearly a year in the Laboratory of the Waterworks at Rotterdam, consists in lowering the content of crystal violet to half of the original amount and in raising the $\mathrm{pH}$ to 6.8 .

The medium is now prepared as follows : $0.3 \%$ bacto-tryptone, $0.04 \% \quad \mathrm{~K}_{2} \mathrm{HPO}_{4}, 0.1 \% \mathrm{HCOONa}, 0.00005 \%$ crystal violet, $\mathrm{pH}=6.8$. Dissolve in $1800 \mathrm{ml}$ distilled water 30 grams bactotryptone, 4 grams $\mathrm{K}_{2} \mathrm{HPO}_{4}$ and 1.3 grams $\mathrm{NaCl}$. Filter through Swedish filterpaper, add $\pm 13 \mathrm{ml} \mathrm{n} \mathrm{HCl}$. Sterilise in Koch's steriliser for an hour. Add $50 \mathrm{ml}$ sterilised $20 \%$ sodium formate solution, $5 \mathrm{ml}$ sterilised aqueous crystal violet solution $(1: 1000)$ and sterile distilled water up to $2000 \mathrm{ml}$.

Cultivate in completely filled stoppered glass bottles at $44-45^{\circ} \mathrm{C}$. in a $1: 5$ dilution of the medium. For this purpose supply the glass bottle with one fifth of its content with the culture medium, add the water to be tested either undiluted or in known dilution and fill in the latter case the bottle with sterile water. Test for indol and gas production after 24 and 48 hours. Gas production is often very slight; in such case attention has to be paid to an eventual growth of coli bacteria at the bottom of the glass bottle, which may be rendered visible by shaking the bottle gently.

Indol reagents : 2 grams p. dimethylamino-benzaldehyde in 190 $\mathrm{ml} 90 \%$ alcohol and $40 \mathrm{ml} 25 \% \mathrm{HCl}$. Bring the reagent by means of a pipette as a thin layer over an aliquot of the culture solution in a test tube and heat this in the small flame of a Bunsen burner.

I) cf. T. Folpmers, Antonie van Leeuwenhoek 6, 22, $1939-1940$. 